\title{
Peran Pemediasi Motivasi pada Pengaruh Komitmen Organisasional dan Komitmen Profesional terhadap Kepuasan Kerja Auditor
}

Ardiani Ika Sulistyawati ${ }^{1}$

${ }^{1}$ Universitas Semarang (USM), Jalan Soekarno-Hatta, Tlogosari Kulon, Semarang, Jawa Tengah, 50196

\section{N F O A R T I K E L JEL Classification: $H 83$ \\ L44}

\section{Keywords:}

organizational commitment, professional commitment, job satisfaction, motivation

\begin{abstract}
A B S T R A C $\mathbf{T}$
Job satisfaction is very important for any profession, is no exception for professional auditors. Job satisfaction auditors increasingly paid attention to improving the performance of the company or organization so that objectives can be achieved. Many factors can increase job satisfaction, one of which is commitment. The commitment itself is divided into two organizational commitment and professional commitment. How far the influence of commitment on job satisfaction at the re-test in this study with the motivation as an intervening variable. The samples totaling 160 public accountant who worked at Public Accounting Firm (KAP) in Central Java. The method of analysis used path analysis using structural equation model. The hypothesis test result showed that organizational commitment and professional commitment have a significant influence on job satisfaction and motivatioan, motivation has a significan influence on job satisfaction. But contrary to the organizational commitment and professional commitment has no significant effect on employment satisfaction through motivation.
\end{abstract}

\section{A B S T R A K}

Kepuasan kerja sangat penting untuk profesi apa pun, tidak terkecuali bagi auditor profesional. auditor kepuasan kerja semakin memperhatikan meningkatkan kinerja perusahaan atau organisasi sehingga tujuan dapat dicapai. Banyak faktor yang dapat meningkatkan kepuasan kerja, salah satunya adalah komitmen. Komitmen itu sendiri dibagi menjadi dua komitmen organisasi dan komitmen profesional. Seberapa jauh pengaruh komitmen terhadap kepuasan kerja di re-test dalam penelitian ini dengan motivasi sebagai variabel intervening. Sampel berjumlah 160 akuntan publik yang bekerja di Kantor Akuntan Publik (KAP) di Jawa Tengah. Metode analisis yang digunakan analisis jalur menggunakan model persamaan struktural. Hasil uji hipotesis menunjukkan bahwa komitmen organisasi dan komitmen profesional memiliki pengaruh yang signifikan terhadap kepuasan kerja dan motivatioan, motivasi memiliki pengaruh signifikan terhadap kepuasan kerja. Tapi bertentangan dengan komitmen organisasi dan profesional komitmen tidak berpengaruh signifikan terhadap kepuasan kerja melalui motivasi

\section{Pendahuluan}

Keberhasilan dan kinerja seseorang dalam dunia kerja banyak ditentukan oleh tingkat kompetensi, profesionalisme, dan juga komitmen terhadap bidang yang ditekuninya

*Email Korespondensi: 'ardiani.ika2005@gmail.com 
(Amilin dan Dewi, 2008). Tidak diragukan lagi, tingkat kompetensi dan profesionalisme harus dimiliki setiap profesi, karena dua hal tersebut adalah modal dasar bagi semua profesi untuk mendapatkan kepuasan kinerja tidak terkecuali bagi auditor dalam melaksanakan prosedur auditnya.

Aranya et.al (1982) dalam Tris-naningsih (2003) menganalisis komitmen organisasional dan komitmen profesional pada kepuasan kerja para akuntan yang dipekerjakan. Dengan menggunakan ko-mitmen organisasional dan profesional sebagai predictor kepuasan kerja, dan me-laporkan adanya suatu korelasi nyata se-cara statistik antara komitmen organisasional dan kepuasan kerja. Komitmen profesional mempengaruhi kepuasan kerja secara tidak langsung melalui komitmen organisasional.

Bila dilihat dari segi non-skill, komitmen adalah hal yang cukup berpengaruh. Suatu komitmen organisasional menunjukan suatu daya dari seseorang dalam mengidentifikasikan keterlibatanya dalam suatu bagian organisasi (Mowday, Porter dan Steers, 1982 dalam Setiana, 2006). Komitmen merupakan suatu sifat dan perilaku yang dapat dipandang sebagai penggerak motivasi di dalam diri seseorang. Komitmen organisasional dapat menimbulkan suatu rasa ikut memiliki (sense of belonging) bagi pekerja terhadap organisasi atau perusahaan tempat ia bekerja. Dengan rasa ikut memiliki tersebut, maka seseorang merasa jiwanya terikat dengan nilainilai organisasi yang ada, sehingga diharapkan dirinya dapat termotivasi dalam menjalani rutinitas yang berkaitan dengan pekerjaan yang digelutinya (Trisnaningsih,2003).

Di samping komitmen organisasional, adanya orientasi profesional yang mendasari timbulnya komitmen profesional tampaknya juga berpengaruh terhadap kepuasan kerja. Komitmen profesional pada dasarnya merupakan persepsi yang berintikan loyalitas, tekat, dan harapan seseorang yang dituntun oleh sistem nilai norma yang mengarahkan orang tersebut untuk bertindak atau bekerja sesuai dengan prosedur tertentu dalam upaya menjalankan tugasnya dengan tingkat keberhasilan tinggi.
Para profesional lebih senang mengasosiasikan dirinya dengan organisasi profesi mereka dalam melaksanakan tugas-tugasnya dan para profesional juga ingin lebih mentaati norma, aturan, kode etik profesi dalam memecahkan masalah-masalah yang mereka hadapi (Copur, 1990 dalam Restuningdiah, 2009).

Penelitian mengenai komitmen dan kepuasan kerja merupakan topik yang menarik untuk diteliti lebih lanjut. Gregson (1992) dalam Restuningdiah (2009) mengatakan kepuasan kerja merupakan pertanda awal suatu komitmen organisasional dalam sebuah pergantian akuntan yang bekerja pada kantor akuntan publik. Dengan banyaknya pergantian akuntan publik yang terjadi di Kantor Akuntan Publik menunjukan suatu masalah bahwa tingkat komitmen organisasional auditor rendah.

Sedangkan Bateman dan Strasser (1984) dalam Trisnaningsih (2003) menyatakan bahwa komitmen mendahului kepuasan kerja, bahwa dengan adanya komitmen setidaknya dapat mempengaruhi kinerja baik secara langsung maupun tidak langsung. Namun demikian penelitian Sinta Setiana (2005) dan Diah Wijayanti (2008) menemukan bahwa tidak ada pengaruh signifikan antara komitmen terhadap kepuasan kerja. Berbeda dengan penelitian Trisnaningsih (2003) yang menyatakan bahwa adanya pengaruh signifikan antara komitmen terhadap kepuasan kerja.

Dalam mencapai kepuasan kerja, seseorang juga harus memiliki motivasi dalam dirinya. Motivasi juga diperlukan untuk mendorong suatu profesi untuk melakukan pekerjaannya dan mengembangkan kemampuanya dalam melakukan pekerjaan (Trisnaningsih, 2003). Namun belum bisa dipastikan seberapa besar pengaruh motivasi dengan komitmen organisasional maupun komitmen profesional, dan bagaimana ketiga unsur tersebut mempunyai dampak bagi kepuasan kerja.

Penelitian ini mencoba untuk menganalisis kembali bagaimana pengaruh komitmen organisasional dan komitmen profesional terhadap kepuasan kerja auditor dengan menambahkan motivasi sebagai variabel 
intervening. Alasan pemilihan kantor akuntan publik sebagai objek penelitian adalah untuk mengetahui pengaruh komitmen organisasional auditor terhadap kepuasan kerja pada kantor akuntan publik. Di mana auditor adalah suatu profesi yang erat kaitanya dengan perkembangan ilmu akuntansi. Peran auditor dalam pemeriksaan laporan keuangan tentunya amat bermanfaat bagi penggunaan laporan keuangan.

\section{Telaah Teori dan Pengembangan Hipotesis}

Komitmen anggota organisasi menjadi hal penting bagisebuah organisasi dalammenciptakan kelangsungan hidup sebuah organisasi apapun bentuk organisasinya. Komitmen menunjukan hasrat karyawan sebuah perusahaan untuk tetap tinggal dan bekerja serta mengabdikan diri bagi perusahaan (Amilin dan Rosita, 2008). Mowday et al (1979) dalam Tranggono (2007) menyatakan bahwa komitmen menunjukan keyakinan dan dukungan yang kuat terhadap nilai dan sarana (goal) yang ingin dicapai oleh suatu organisasi. Komitmen organisasional menyangkut tiga sikap yaitu rasa mengidentifikasikan dengan tujuan organisasi, rasa keterlibatan dengan tugas organisasi, dan rasa kesetiaan kepada organisasi (Ferris dan Aranya, 1983 dalam Setiana, 2006). Robbins dan Jugde (2008) mendefinisikan komitmen organisasional sebagai suatu keadaan di mana seorang karyawan memihak organisasi tertentu serta tujuan-tujuan dan keinginanya untuk mempertahankan keanggotaan dalam organisasi tersebut.

Komitmen profesional pada dasarnya merupakan persepsi yang berintikan loyalitas, tekad dan harapan seseorang dengan dituntun oleh sistem nilai dan norma yang akan mengarahkan orang tersebut untuk bertindak atau bekerja sesuai prosedur-prosedur tertentu dalam upaya menjalankan tugasnya dengan tingkat keberhasilan yang tinggi (Larkin, 1990 dalam Diah Wijayanti, 2008). Komitmen profesional yang didasari oleh pemahaman perilaku, sikap dan orientasi seseorang dalam melaksanakan tugas-tugas merupakan cerminan dari aturan, norma dan kode etik profesinya.
Motivasi sebagai keadaan dalam pribadi seseorang yang mendorong keinginan individu untuk melakukan kegiatan-kegiatan tertentu untuk mencapai suatu tujuan (Reksohadiprojo dan Handoko, 2000). Gibson et.al (1985) mengungkapkan motivasi sebagai konsep yang kita gunakan jika kita menguraikan kekuatankekuatan yang bekerja terhadap atau dalam diri individu untuk memulai dan mengarahkan perilaku. Konsep ini digunakan untukmenjelaskan perbedaan-perbedaan dalam intensitas perilaku, di mana perilaku yang lebih bersemangat adalah hasil dari tingkat motivasi lebih kuat.

Kepuasan kerja (job satisfaction) dapat didefinisikan sebagai suatu perasaan positif tentang pekerjaan seseorang yang merupakan hasil dari sebuah evaluasi karakteristiknya. Seseorang dengan tingkat kepuasan kerja yang tinggi memiliki perasaan-perasaan positif tentang pekerjaan yang negatif tentang pekerjaan tersebut, sementara seseorang yang tidak puas memiliki perasaan negatif tentang pekerjaanya tersebut (Robbins dan Judge, 2008). Kepuasan kerja merupakan perasaan senang atau tidaknya seseorang yang relatifterhadap pekerjaaanya yang berbeda dari pemikiran objektif dan keinginan perilaku. Apabila karyawan bergabung dalam suatu organisasi, ia membawa serta keinginan, kebutuhan, hasrat dan pengalaman masa lalu menyatu membentuk harapan kerja (Davis dan Newstron, 1985).

\section{Hubungan Komitmen Organisasional dengan Kepuasan Kerja}

Kepuasan kerja dan komitmen organisasional adalah dua hal yang sering dijadikan pertimbangan saat mengkaji pergantian akuntan yang bekerja (Poznanski dan Bline, 1997 dalam Restuningdiah, 2009). Beberapa penelitian terdahulu, misalnya Gregson (1992) dalam Restuningdiah (2009) melaporkan hasil penelitiannya bahwa kepuasan kerja sebagai pertanda awal terhadap komitmen organisasional dalam sebuah model pergantian akuntan yang bekerja, namun terdapat batasan dalam penelitian tersebut, karena masalah identifikasi sebuah model dengan hubungan timbal balik antara 
kepuasan kerja dengan komitmen organisasional tidak dapat diuji.

Dengan menggunakan komitmen organisasional dan komitmen profesional sebagai prediktor kepuasan kerja, dan melaporkan adanya suatu korelasi nyata secara signifikan antara komitmen organisasional dan kepuasan kerja (Sri Trisnaningsih, 2003). Norris dan Niebuhr (1983), juga Meixner dan Bline (1989) dalam Setiana (2006) mendukung kesimpulan Aranya et al (1982) bahwa komitmen organisasional dan komitmen profesional adalah saling melengkapi dan harmonis serta mempunyai hubungan yang signifikan terhadap kepuasan kerja.

$\mathrm{H}_{1}$ : Komitmen organisasional mempunyai pengaruh yang signifikan terhadap kepuasan kerja

\section{Hubungan Komitmen Profesional terhadap Kepuasan Kerja}

Komitmen profesional dapat didefinisikan sebagai : (1) sebuah kepercayaan pada dan penerimaan terhadap tujuan-tujuan dan nilainilai dari profesi, (2) sebuah kemauan untuk menggunakan usaha yang sungguh-sungguh guna kepentingan profesi, (3) sebuah keinginan untuk memelihara keanggotaan dalam profesi (Aranya et al, 1981 dalam Setiana, 2006). Sedangkan kepuasan kerja adalah suatu sikap umum terhadap pekerjaan seseorang sebagai perbedaan antara banyaknya ganjaran yang diterima pekerja dan banyaknya yang diyakini yang seharusnya diterima (Robbins,1996 dalam Sri Trisnaningsih, 2003).

Penelitian yang dilakukan oleh Norris dan Neibuhr(1984), Kalbers dan Fogarty (1995) dalam Restuningdiah (2009) terhadap akuntan publik dan auditor menunjukkan bahwa profesionalisme mempunyai hubungan positif dengan kepuasan kerja. Semakin tinggi profesionalisme, maka semakin tinggi pula kepuasan kerja akuntan.

$\mathrm{H}_{2}$ : Komitmen profesional mempunyai pengaruh yang signifikan terhadap kepuasan kerja.

\section{Hubungan Komitmen Organisasional dengan Motivasi}

Komitmen organisasional merupakan tingkat sampai sejauh mana seorang karyawan mamihak pada suatu organisasi tertentu dantujuantujuannya, serta berniat untuk mempertahankan keanggotaannya dalam organisasi itu. Komitmen organisasional juga merupakan nilai personal, yang kadang-kadang mengacu pada sikap loyal pada perusahaan atau komitmen pada perusahaan (Ikhsan dan Ishak,2008). Sedangkan motivasi adalah keadaan dalam pribadi seseorang yang mendorong keinginan individu untuk melakukan kegiatan-kegiatan tertentu untuk mencapai suatu tujuan (Reksohadiprojo dan Handoko, 2000). Menurut Robbins (1996) dalam Badjuri (2008) motivasi merupakan hasil interaksi antara individu dan situasinya, sehingga setiap manusia mempunyai inovasi yang berbeda antara satu dengan yang lain. Selanjutnya Robbins menyatakan bahwa ada tiga kata kunci utama tentang motivasi dalam perilaku organisasi, yaitu : kemauan untuk berusaha, pencapaian, tujuan organisasi. Dengan adanya komitmen organisasional pada seseorang akan menimbulkan motivasi untuk bekerja sebaik-baiknya pada suatu organisasi sebagai upaya mewujudkan tujuan bersama, sebagai konsekuensi agar komitmen tersebut dapat terwujud atau tercapai. Karena motivasi merupakan faktoryang mendorong orang untuk bertindak atau berperilaku dengan caracara tertentu sesuai komitmennya (Trisnaningsih, 2003).

$\mathrm{H}_{3}$ : Komitmen organisasional mempunyai pengaruh yang signifikan terhadap motivasi.

\section{Hubungan Komitmen Profesional dengan Motivasi}

Komitmen profesional juga dapat dikatakan sebagai tingkat loyalitas individu pada profesinya seperti yang telah dipersepsikan oleh individu tersebut (Larkin, 1990 dalam Setiana, 2006). Komitmen profesional mendasari perilaku, sikap dan orientasi profesional seseorang dalam menjalankan tugas atau pekerjaannya. Sedangkan motivasi adalah keadaan pribadi seseorang yang mendorong keinginan individu melakukan kegiatan tertentu guna mencapai suatu tujuan (Reksohadiprojo dan Handoko, 2000). Dengan demikian, komitmen profesional akan mempengaruhi motivasi seseorang dalam 
bekerja khususnya guna mendapatkan predikat sebagai seorang profesional sejati sebagai suatu kebanggaan di dalam suatu asosiasi profesi (Trisnaningsih, 2003).

$\mathrm{H}_{4}$ : Komitmen profesional mempunyai pengaruh yang signifikan terhadap motivasi.

\section{Hubungan Motivasi terhadap Kepuasan Kerja}

Hakikat kepuasan kerja adalah perasaan senang ataupun tidak senang terhadap pekerjaan yang dilakukannnya. Perasaan senang dan tidak senang ini muncul yang disebabkan karena pada saat karyawan bekerja mereka membawa serta keinginan, kebutuhan dan pengalaman masa lalu yang membentuk harapan kerja mereka. Makin tinggi harapan kerja ini dapat terpenuhi, makin tinggi tingkat kepuasan kerja karyawan. Kepuasan kerja tidak dapat dipisahkan oleh motivasi kerja yang seringkali merupakan harapan kerja karyawan(Davis dan Newstrom, 1985). Seseorang yang tidak termotivasi dalam bekerja tidak dapat menjalani pekerjaannya dengan sepenuh hati. Hal inilah yang sering menjadikan seseorang tidak berhasil dalam kariernya. Gambaran yang akurat tentang hubungan ini adalah bahwa motivasi kerja menyumbang timbulnya kepuasan kerja yang tinggi. Kepuasan kerja akan tinggi apabila keinginan dan kebutuhan karyawan akan menjadi motivasi kerja terpenuhi (Badjuri, 2008).

$\mathrm{H}_{5}$ : Motivasi mempunyai pengaruh yang signifikan terhadap kepuasan kerja.

\section{Hubungan Komitmen Organisasional terhadap Kepuasan Kerja melalui Motivasi}

Seseorang yang bergabung dengan suatu organisasi tentunya membawa keinginankeinginan, kebutuhan dan pengalaman masa lalu yang membentuk harapan kerja baginya, dan bersama-sama dengan organisasinya berusaha mencapai tujuan bersama. Untuk dapat bekerja sama dengan baik, seorang karyawan harus mempunyai komitmen yang tinggi pada organisasinya. Komitmen organisasional tumbuh manakala harapan kerja ini akan menimbulkan kepuasan kerja. Tingkat kepuasan kerja banyak menunjukan kesesuaiannya dengan harapan kerja yang sering merupakan motivasi kerja
(Trisnaningsih, 2003).

$\mathrm{H}_{6}$ : Komitmen organisasional mempunyai pengaruh yang signifikan terhadap kepuasan kerja melalui motivasi sebagai variabel intervening.

\section{Hubungan Komitmen Profesional terhadap Kepuasan Kerja melalui Motivasi}

Suatu komitmen profesional pada dasarnya merupakan persepsi yang berintikan loyalitas, tekad dan harapan seseorang dengan dituntun oleh sistem nilai atau norma yang akan mengarahkan orang tersebut untuk bertindak atau bekerja sesuai prosedur-prosedur tertentu dalam upaya menjalankan tugasnya dengan tingkat keberhasilan yang tinggi (Larkin, 1990 dalam Wijayanti, 2008). Hal ini dapat menjadikan komitmen profesional sebagai gagasan yang mendorong motivasi seseorang dalam bekerja. Motivasi merupakan konsep yang digunakan jika kita menguraikan kekuatan-kekuatan yang bekerja terhadap atau di dalam diri individu untuk memulai dan mengarahkan perilaku (Gibson et.al, 1985).

Kepuasan kerja akan tinggi bila keinginan dan kebutuhan karyawan yang menjadikan motivasi kerja dapat terpenuhi. Kompensasi dari organisasi berupa penghargaan (reward) sesuai profesinya, akan menimbulkan kepuasan kerja karena mereka merasa bahwa organisasi telah memperhatikan kebutuhan dan pengharapan kerja mereka. Dengan demikian, apabila seseorang atau auditor mempunyai komitmen profesional maka akan mengarahkan atau menimbulkan motivasi secara profesional, dengan adanya motivasi yang tinggi maka kan timbul kepuasan kerja (Setiana, 2006).

$\mathrm{H}_{7}$ : Komitmen profesional mempunyai pengaruh yang signifikan terhadap kepuasan kerja melalui motivasi sebagai variabel intervening.

Gambaran kerangka pikir sebagaimana tampak gambar.1 


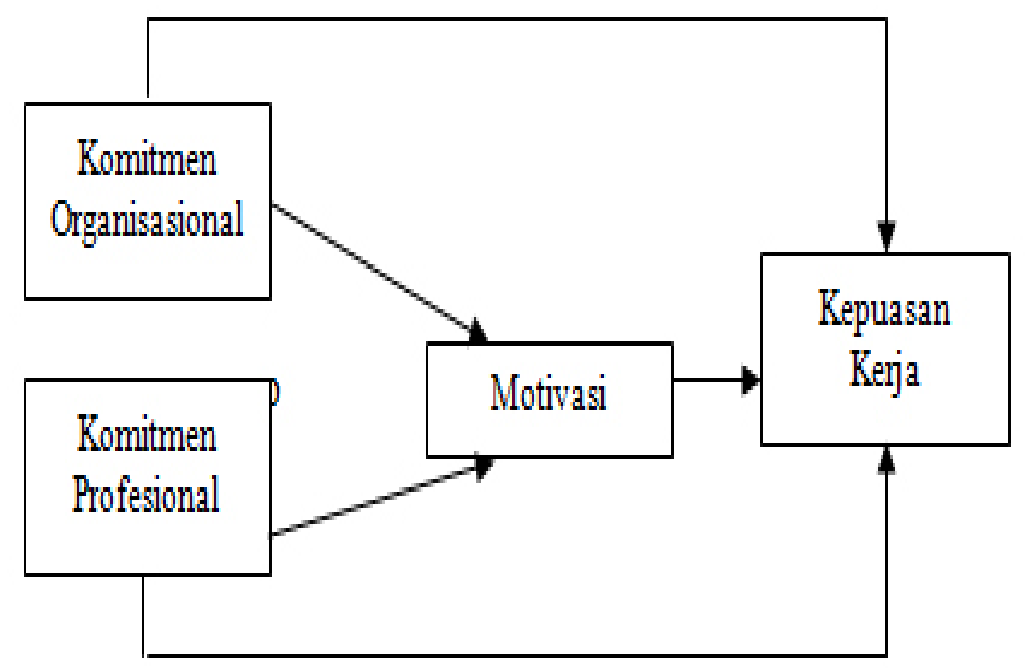

Gambar 1. Kerangka Pikir Penelitian

\section{Metode}

Populasi dalam penelitian ini adalah auditor yang bekerja di Kantor Akuntan Publik di Jawa Tengah. Sampel adalah meneliti sebagian dari elemen-elemen populasi (Indriantoro dan Supomo, 2002). Teknik yang digunakan dalam pengambilan sampel pada penelitian ini adalah convenience sampling. Convenience sampling atau pengambilan sampel berdasarkan kemudahan adalah memilih sampel dari elemen populasi (orang atau kejadian) yang datanya mudah diperoleh peneliti (Indriantoro dan Supomo, 2002).

Metode pengumpulan data dalam penelitian ini dilakukan dengan metode survey, yaitu metode pengumpulan data primer yang diperoleh secara langsung dari sumber aslinya (Indriantoro dan Supomo, 2002). Pengumpulan data dilakukan melalui kuesioner yang diberikan secara langsung dan dikirim melalui pos ke Kantor Akuntan Publik (KAP) tempat responden bekerja.

Pada permodelan yang menggunakan teknik analisis SEM ditempuh beberapa langkah yang harus dilakukan. Hair et al. (1998) dalam Ghozali (2005) mengajukan tahapan permodelan dan analisis persamaan struktural menjadi 7 langkah yaitu: (1) pengembangan model secara teoritis, (2) menyusun diagram jalur (path diagram), (3) mengubah diagram jalur menjadi persamaan struktural, (4) memilih matrik input untuk analisis data, (5) menilai identifikasi model, (6) mengevaluasi estimasi model, dan (7) interpretasi terhadap model. Berikut ini akan dijelaskan secara detail masing-masing tahapan.

\section{Hasil Penelitian dan Pembahasan}

Subyek penelitian ini adalah jajaran auditor di Kantor Akuntan Publik (KAP) di Jawa Tengah. Penelitian dilakukan pada bulan awal Juli 2010 dengan mengirimkan 160 kuesioner kepada 15 Kantor Akuntan Publik (KAP). Namun demikian ternyata hanya 124 kuesioner yang kembali dan 36 diantaranya tidak kembali dan 4 lainnya tidak lengkap, sehingga hanya 120 kuesioner saja yang dapat diolah. Komitmen organisasional, rata-rata total jawaban responden adalah sebesar 44,05 dengan standar deviasi sebesar 7,89 menunjukan variasi jawaban responden yang tinggi. Untuk penilaian terhadap variabel komitmen profesional, rata-rata total jawaban sebesar 67,24 dengan standar deviasi 12,6 menunjukan variasi jawaban responden yang tinggi. Penilaian terhadap variabel motivasi, rata-rata total jawaban sebesar 38,13 dengan standar deviasi 6,37 menunjukan variasi jawaban responden yang tinggi. Pada variabel kepuasan kerja rata-rata total jawaban sebesar 14,75 dengan standar deviasi 2,36 menunjukan variasi jawaban responden yang tinggi. (tabel.1) 
Tabel 1. Hasil Uji Reliabilitas

\begin{tabular}{|c|c|c|}
\hline Variabel & Reliabilty & $\begin{array}{l}\text { Variance } \\
\text { Extract }\end{array}$ \\
\hline Komitmen Organisasional & 0,928 & 0,517 \\
\hline Komitmen Profesional & 0,954 & 0,535 \\
\hline Motivasi & 0,920 & 0,535 \\
\hline Kepuasan Kerja & 0,843 & 0,574 \\
\hline
\end{tabular}

Hasil pengujian reliabiliy dan variance extract terhadap masing-masing variabel laten atas dimensi-dimensi pembentuknya menunjukkan bahwa semua variabel menunjukkan sebagai suatu ukuran yang reliabel karena masingmasing memiliki reliability yang lebih besar dari 0,7. Hasil pengujian variance extract juga sudah meenunjukkan bahwa masing-masing variabel laten merupakan hasil ekstraksi yang cukup besar dari dimensi-dimensinya. Hal ini ditunjukkan dari nilai variance extract dari masing-amsing variabel adalah lebih dari 0,5. (tabel 2)

Dengan adanya model yang sudah fit maka pengujian parameter sebagaimana yang dihipotesiskan dapat diinterpretasikan. Hasil pengujian parameter diperoleh sebagai berikut. (tabel.3)

Tabel 2. Hasil Pengujian Kelayakan Model Structural Equation Model

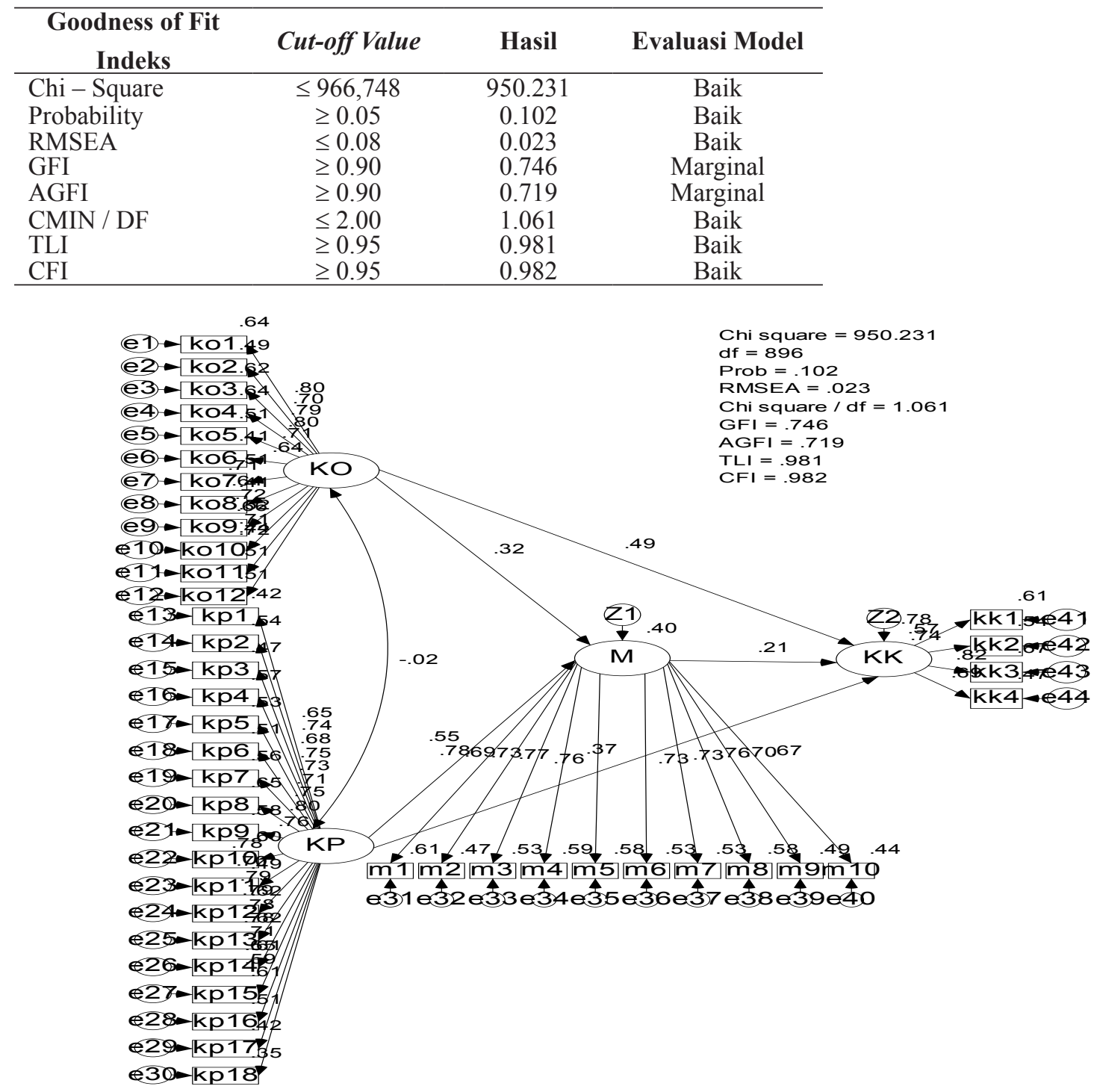

Gambar 1. Hasil Pengujian Structural Equation Model (SEM) 
Tabel 3. Regression Weight Structural Equational

\begin{tabular}{lllrrrrr}
\hline \multicolumn{2}{l}{ Variabel } & & Estimate & S.E. & $\begin{array}{r}\text { Std. } \\
\text { Est }\end{array}$ & C.R. & P \\
\hline $\mathrm{M}$ & $<---$ & KO & 0.421 & 0.117 & 0.323 & 3.610 & 0.000 \\
$\mathrm{M}$ & $<---$ & KP & 0.639 & 0.134 & 0.549 & 4.765 & 0.000 \\
KK & $<---$ & M & 0.173 & 0.085 & 0.212 & 2.027 & 0.043 \\
KK & $<---$ & KO & 0.522 & 0.107 & 0.491 & 4.895 & 0.000 \\
KK & $<---$ & KP & 0.354 & 0.103 & 0.374 & 3.429 & 0.000 \\
\hline
\end{tabular}

Pengaruh komitmen organisasional terhadap kepuasan kerja menunjukkan pengaruh signifikan. Hasil pengujian pengaruh variabel tersebut diperoleh C.R sebesar 4,895 dengan $\mathrm{P}$ sebesar 0,000. Dengan demikian diperoleh nilai signifikansi lebih kecil dari 0,05. Dengan demikian dapat disimpulkan bahwa komitmen organisasional memiliki pengaruh signifikan terhadap kepuasan kerja. Dengan kata lain dapat disimpulkan bahwa auditor dengan komitmen organisasional yang tinggi akan memiliki kepuasan kerja yang tinggi. Hal ini berarti hipotesis 1 diterima.

Pengaruh komitmen profesional terhadap kepuasan kerja menunjukkan pengaruh signifikan. Hasil pengujian pengaruh variabel tersebut diperoleh C.R sebesar 3,429 dengan P sebesar 0,000. Dengan demikian diperoleh nilai signifikansi lebih kecil dari 0,05. Dengan demikian dapat disimpulkan bahwa komitmen profesional memiliki pengaruh signifikan terhadap kepuasan kerja. Dengan kata lain dapat disimpulkan bahwa auditor dengan komitmen profesional yang tinggi akan memiliki kepuasan kerja yang tinggi. Hal ini berarti hipotesis 2 diterima.

Pengaruh komitmen organisasional terhadap motivasi menunjukkan pengaruh signifikan. Hasil pengujian pengaruh variabel tersebut diperoleh C.R sebesar 3,610 dengan $\mathrm{P}$ sebesar 0,000. Dengan demikian diperoleh nilai signifikansi lebih kecil dari 0,05. Dengan demikian dapat disimpulkan bahwa komitmen organisasional memiliki pengaruh signifikan terhadap motivasi. Dengan kata lain dapat disimpulkan bahwa auditor dengan komitmen organisasional yang tinggi akan memiliki motivasi kerja yang tinggi. Hal ini berarti hipotesis 3 diterima. Pengaruh komitmen profesional terhadap motivasi menunjukkan pengaruh signifikan. Hasil pengujian pengaruh variabel tersebut diperoleh C.R sebesar 4,765 dengan P sebesar 0,000. Dengan demikian diperoleh nilai signifikansi lebih kecil dari 0,05. Dengan demikian dapat disimpulkan bahwa komitmen profesional memiliki pengaruh signifikan terhadap motivasi. Dengan kata lain dapat disimpulkan bahwa auditor dengan komitmen profesional yang tinggi akan memiliki motivasi kerja yang tinggi. Hal ini berarti hipotesis 4 diterima.

Pengaruh motivasi terhadap kepuasan kerja menunjukkan pengaruh signifikan. Hasil pengujian pengaruh variabel tersebut diperoleh C.R sebesar 2,027 dengan Psebesar 0,043. Dengan demikian diperoleh nilai signifikansi lebih kecil dari 0,05. Dengan demikian dapat disimpulkan bahwa motivasi memiliki pengaruh signifikan terhadap kepuasan kerja. Dengan kata lain dapat disimpulkan bahwa auditor dengan motivasi yang tinggi akan memiliki kepuasan kerja yang tinggi. Hal ini berarti hipotesis 5 diterima.

Untuk menguji hipotesis 6 dilakukan dengan membandingkan pengaruh langsung dan pengaruh tidak langsung dari komitmen organisasional terhadap kepuasan kerja yaitu dengan dan tanpa melalui motivasi.

$$
\begin{array}{ll}
\text { Pengaruh langsung = } & 0,491 \\
\text { Pengaruh tidak }= & 0,323 \times 0,212= \\
\text { langsung } &
\end{array}
$$

Diperoleh bahwa besarnya pengaruh tidak langsung dari komitmen organisasional terhadap kepuasan kerja melalui motivasi adalah sebesar 0,068 yang menunjukkan lebih kecil dari pengaruh langsungnya yaitu sebesar 0,491. 
Dengan demikian maka motivasi tidak dapat memediasi pengaruh komitmen organisasional terhadap kepuasan kerja. Hal ini berarti hipotesis 6 ditolak.

Untuk menguji hipotesis 7 dilakukan dengan membandingkan pengaruh langsung dan pengaruh tidak langsung dari komitmen profesional terhadap kepuasan kerja yaitu dengan dan tanpa melalui motivasi.

Pengaruh langsung $\quad=0.374$

Pengaruh tidak $=0,549 \times 0,212=$ langsung $\quad 0,116$

Diperoleh bahwa besarnya pengaruh tidak langsung dari komitmen profesional terhadap kepuasan kerja melalui motivasi adalah sebesar 0,116 yang menunjukkan lebih kecil dari pengaruh langsungnya yaitu sebesar 0,374 . Dengan demikian maka motivasi tidak dapat memediasi pengaruh komitmen profesional terhadap kepuasan kerja. Hal ini berarti hipotesis 7 ditolak.

\section{Pengaruh Komitmen Organisasional terhadap Kepuasan Kerja}

Hasil penelitian ini membuktikan bahwa komitmen organisasional berpengaruh signifikan terhadap kepuasan kerja. Kondisi demikian menunjukkan bahwa seorang auditor yang mempunyai komitmen yang tinggi terhadap organisasi yang tinggi dimana mereka bekerja (KAP) tentunya mempunyai perhatian yang tinggi terhadap visi, misi dan pencapaian tujuan organisasi. Keinginan untuk tetap bersama organisasi karena kesesuaian nilai-nilai organisasi dengan nilai-nilai individu auditor dapat mendorong mereka untuk dapat melakukan fungsi dan kewajiban mereka sebagai anggota organisasi. Seorang yang berkomitmen tinggi terhadap organisasi akan memiliki perasaan yang lebih besar untuk menjadikan organisasi mereka dapat memiliki keunggulan. Hasil penelitian ini sesuai dengan penelitian Trisnaningsih (2001) dan Amilin dan Dewi (2008) bahwa komitmen organisasional berpengaruh terhadap kepuasan kerja.
Anggota organisasi yang berpartisipasi secara penuh dalam bekerja berarti karyawan memperhatikan kepentingan - kepentingan organisasi dalam mencapai tujuan-tujuannya. Mereka menjadi lebih peduli terhadap fungsi organisasi yang efektif, sehingga lebih loyal dan berdedikasi dalam melakukan pekerjaan, serta berusaha memelihara perilaku-perilaku yang di-milikinya dalam melakukan tugas pekerjaan tersebut. Mereka akan bekerja keras dan menjalankan seluruh tugas-tugasnya serta tanggung jawabnya dengan baik sehingga pada saatnya akan memberikan kepuasan kerja.

\section{Pengaruh Komitmen Profesional terhadap Kepuasan Kerja}

Hasil penelitian ini menunjukkan bahwa komitmen profesional berpengaruh signifikan terhadap kepuasan kerja. Hasil ini menjelaskan bahwa komitmen profesional merupakan tuntutan di berbagai bidang profesi, tidak terkecuali profesi sebagai auditor independen. Hasil penelitian ini sejalan dengan Trisnaningsih (2001) tetapi bertentangan dengan Setiana (2005) dan Wijayanti (2008). Auditor yang profesional dalam melakukan pemeriksaan diharapkan akan menghasilkan audit yang memenuhi standar yang telah ditetapkan oleh organisasi. Profesionalisme harus selalu ditanamkan kepada auditor dalam menjalankan fungsinya. Dalam hal ini komitmen profesional dapat menjadi elemen motivasi dalam memberikan kontribusi terhadap kinerja. Kinerja auditor yang berpengalaman dalam melakukan pemilihan dan analisis resiko yang terjadi dalam pelaksanaan audit akan dipengaruhi oleh pengetahuan yang dimilikinya. Peningkatan komitmen profesional ini akan menunjang komitmen mereka terhadap organisasi. Dari upaya profesionalitas tersebut, akan memberikan sikap positif terhadap profesi mereka sehingga kepuasan kerja atas dasar profesionalisme setelah melalui komitmen tersebut akan lebih besar.

\section{Pengaruh Komitmen Organisasional terhadap Motivasi}

Hasil riset ini menyimpulkan bahwa komitmen organisasional berpengaruh signifikan 
terhadap motivasi. Hal ini berarti bahwa dalam komitmen oganisasi yang dimiliki oleh auditor menunjukkan kemauan mereka untuk bekerja demi perusahaan. Keinginan yang kuat tersebut akan mem-berikan satu tekad untuk bekerja demi perusahaan. Dengan demikian maka semangat yang dimiliki oleh auditor dengan komitmen organisasional yang kuat akan semakin meningkatkan manfaatnya demi peningkatan motivasi kerjanya. Hasil penelitian ini sesuai dengan penelitian Trisnaningsih (2001).

\section{Pengaruh Komitmen Profesional terhadap Motivasi}

Penelitian ini membuktikan bahwa komitmen profesional berpengaruh signifikan terhadap motivasi. Artinya, komitmen terhadap profesi dari akuntan publik, nampaknya mendorong setiap auditor untuk dapat bertindak secara profesional. Dengan sikap profesional terhadap profesi mereka berarti auditor telah memberikan salah satu bentuk keinginan mereka terhadappekerjaanmereka.Peningkatankomitmen profesional ini akan menunjang motivasi mereka terhadap kepentingan organisasi. Hasil penelitian ini sejalan dengan penelitian Trisnaningsih (2001) dan Setiana (2005) yang menyatakan adanya pengaruh komitmen profesional terhadap motivasi.

\section{Pengaruh Motivasi terhadap Kepuasan Kerja}

Hasil penelitian membuktikan bahwa motivasi berpengaruh signifikan terhadap kepuasan kerja. Motivasi kerja merupakan bagian penting dalam kerja. Motivasi yang tidak baik bisa mempunyai dampak yang luas terhadap kehidupan kerja, misalnya ketidakpuasan kerja serta keinginan untuk keluar dari pekerjaan, dan sebaliknya motivasi yang tinggi dapat meningkatkan keinginan untuk mengerjakan tugas agar lebih cepat terselesaikan. Hasil penelitian ini sesuai dengan penelitian Trisnaningsih (2001). Komitmen profesional dari akuntan publik terbukti dapat mendorong setiap auditor untuk dapat bertindak secara profesional. Peningkatan komitmen profesional ini akan menunjang motivasi mereka terhadap kepentingan organisasi.

\section{Pengaruh Komitmen Organisasional terhadap} Kepuasan Kerja Melalui Motivasi

Pengujian hipotesis 6 dalam hal ini untuk melakukan pengujian dengan pengaruh variabel motivasi sebagai variabel intevening terhadap pengaruh komitmen organisasional terhadap kepuasan kerja. Hasil pengujian mendapatkan bahwa motivasi tidak mampu memediasi (intervening) pengaruh komitmen organisasional terhadap kepuasan kerja. Hal ini menjelaskan bahwa meskipun auditor tidak memiliki motivasi yang kuat namun ketika auditor juga memiliki komitmen organisasional yang tinggi, maka kepuasan kerja akan dapat diperolehnya sehingga motivasi hanya memberikan peran yang kurang dominan. Dalam hal ini komitmen organisasional yang tinggi membuat seseorang peduli dengan nasib organisasinya dan memiliki perhatian yang tinggi terhadap pencapaian organisasi. Bila seseorang termotivasi maka ia akan berupaya sekuat tenaga untuk mencapai tujuan. Dengan adanya motivasi kerja ini akan mendorong pula seseorang untuk melakukan suatu kegiatan dalam suatu pekerjaan dalam organisasi dengan optimal.

\section{Pengaruh Komitmen Profesional terhadap Kepuasan Kerja Melalui Motivasi}

Pengujian hipotesis 7 dalam hal ini untuk melakukan pengujian dengan pengaruh variabel motivasi sebagai variabel intervening terhadap pengaruh komitmen profesional terhadap kepuasan kerja. Hasil pengujian mendapatkan bahwa motivasi kurang dapat memediasi pengaruh komitmen profesi terhadap kepuasan kerja. Dengan adanya motivasi kerja, maka semangat kerja para auditor profesional bersedia dan rela untuk mengerahkan kemampuan dalam bentuk keahlian, ketrampilan, tenaga dan waktu demi tanggung jawab terhadap profesinya. Auditor yang loyal terhadap profesinya akan menjalankan norma-norma, aturan-aturan, kode etik profesi dan tujuan dari profesinya yaitu mendapat keberhasilan yang tinggi dalam bekerja. Keberhasilan dalam profesi seseorang merupakan wujud kinerja yang optimal. Maka komitmen profesional yang tinggi nampaknya lebih dominan 
dalam menunjang kepuasan kerjanya sehingga motivasi kerja hanya memberikan peran tidak begitu besar.

\section{Simpulan, Keterbatasan, dan Implikasi Hasil Penelitian}

Berdasarkan hasil analisis data dalam penelitian ini menunjukan bahwa komitmen organisasional dan komitmen profesional mempunyai pengaruh signifikan terhadap kepuasan kerja. Temuan ini mendukung hasil penelitian sebelumnya, yaitu Trisnaningsih (2003), Amilin dan Dewi (2008), dan Nurika Restuningdiah (2009). Hasil analisis data dalam penelitian ini juga membuktikan bahwa komitmen organisasional dan komitmen profesional berpengaruh secara signifikan terhadap motivasi. Temuan ini mendukung hasil penelitian sebelumnya, yaitu Setiana (2005). Hasil penelitian ini juga membuktikan bahwa motivasi mempunyai pengaruh signifikan terhadap kepuasan kerja dan mendukung hasil penelitian Trisnaningsih (2003). Pengaruh komitmen organisasional dan komitmen profesional melalui motivasi tidak berpengaruh signifikan terhadap kepuasan kerja.

Penelitian selanjutnya diharapkan dapat menambah obyek penelitian pada profesi akuntan perusahaan dan akuntan pemerintah. Hal ini dimaksud untuk memperjelas hubungan komitmen dengan kepuasan kerja. Selain itu bagi penelitian selanjutnya dapat mempertimbangkan model regresi lain seperti misalnya model moderating untuk memperjelas arah hubungan variabel-variabel tersebut dengan kepuasan kerja.

\section{Daftar Rujukan}

Amilin, dan Rosita Dewi, 2008, Pengaruh Komitmen Organisasi terhadap Kepuasaan Kerja Akuntan Publik dengan Role Stress sebagai Variabel Moderating, Jurnal Akuntansi dan Auditing Indonesia, Vol.12, No.1, Juni.

Badjuri, Achmad, 2008, Pengaruh Komitmen Organisasional dan Profesional terhadap
Kepuasan Kerja Auditor dengan Motivasi sebagai Variabel Intervening, Tesis, Magister Sains Akuntansi, Undip, Semarang.

Davis, Keith dan Newtrom.W, 1995, Perilaku dalam Organisasi, Jilid 1, Edisi ke tujuh, Erlangga, Jakarta.

Ghozali, Imam, 2005, Model Persamaan Struktural Konsep dan Aplikasi Dengan Program AMOS Ver. 5.0, Badan Penerbit Universitas Diponegoro, Semarang.

Gibson, Ivancevich, Donnelly, 1985, Organisasi : Perilaku, Struktur dan Proses (terjemahan), Edisi Kelima, Erlangga, Jakarta.

Ikhsan, Arfan dan Muhammad Ishak, 2008, Akuntansi Keperilakuan, Salemba Empat, Jakarta.

Indriantoro, Nur dan Bambang Supomo, 2002, Metodologi Penelitian Bisnis untukAkuntansi dan Manajemen, BPFE, Yogyakarta.

Lekatompessy, Jantje Eduard, 2003, Hubungan Profesionalisme dengan Konsekuensinya : Komitmen Organisasional, Kepuasan Kerja, Prestasi Kerja, dan Keinginan Berpindah (Studi Empiris di Lingkungan Akuntan Publik), Jurnal Bisnis dan Akuntansi, Vol.5, No.1, April.

Luthans, Fred, 2006, Perilaku Organisasi, Penerbit Andi, Yogyakarta.

Reksohadiprojo, Sukanto dan Handoko, 2000, Organisasi Perusahaan : Teori, Struktur, dan Perilaku, Edisi Dua, BPFE, Yogjakarta.

Restuningdiah, Nurika, 2009, Pengaruh

Komitmen Profesional terhadap Kepuasan Kerja Akuntan Pendidik melalui Komitmen Organisasional, Robbins, Stephen P dan Judge, Timothy A, 2008. Perilaku Organisasi (terjemahan), Edisi Duabelas, Salemba Empat, Jakarta.

Setiana, Sinta, 2006, Uji Model Variabel Komitmen Organisasional, Komitmen Profesional dan Kepuasan Kerja Auditor : Motivasi sebagai Variabel Intervening, Jurnal Ilmiah Akuntansi, Vol.V, No.1, Mei.

Tranggono, Rahadyan Probo, 2007, Pengaruh KOmitmen terhadap Kepuasan Kerja Auditor dengan Motivasi sebagai Variabel Intervening, Skripsi, Fakultas Ekonomi STIE 
Stikubank, Semarang.

Trisnaningsih, Sri, 2003, Pengaruh Komitmen terhadap Kepuasan Kerja Auditor: Motivasi sebagai Variabel Intervening, Jurnal Riset Akuntansi Indonesia, Vol.6, No.2, Mei.

Wijayanti, Diah, 2008, Pengaruh Komitmen terhadap Kepuasan Kerja Auditor Internal: Motivasi sebagai Variabel Moderating, Simposium Nasional Akuntansi XI, Pontianak. 